Choice Experiment Performed on the Fresh Black Slavonian Pig's Meat: A Preliminary Study

Eksperiment odabira na svježem mesu crne slavonske svinje: preliminarno istraživanje

Jelić Milković, S., Lončarić, R., Zmaić, K., Kranjac, D., Canavari, $M$.

Poljoprivreda/Agriculture

ISSN: 1848-8080 (Online)

ISSN: 1330-7142 (Print)

https://doi.org/10.18047/poljo.27.2.10

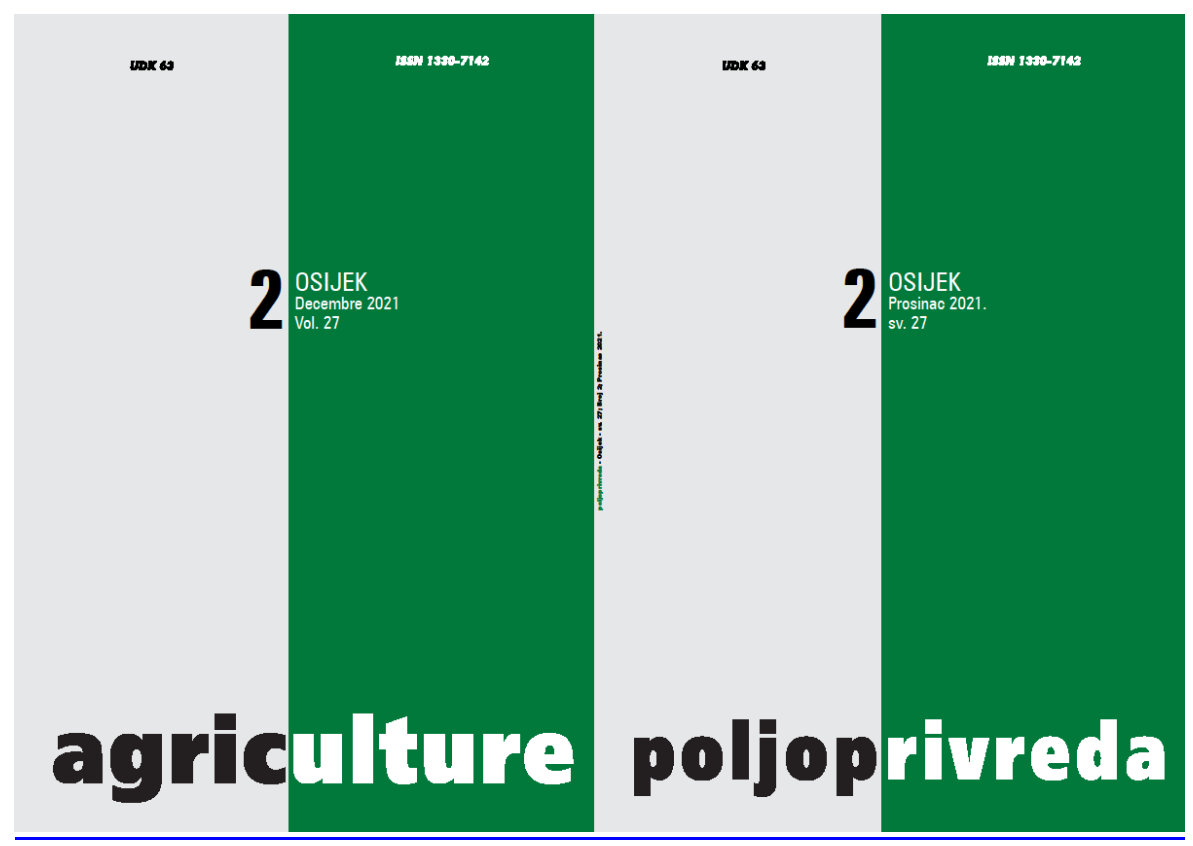

Fakultet agrobiotehničkih znanosti Osijek, Poljoprivredni institut Osijek

Faculty of Agrobiotechnical Sciences Osijek, Agricultural Institute Osijek 


\title{
CHOICE EXPERIMENT PERFORMED ON THE FRESH BLACK SLAVONIAN PIG'S MEAT: A PRELIMINARY STUDY
}

Jelić Milković, S. (1), Lončarić, R. (1), Zmaić, K. (1), Kranjac, D. (1), Canavari, M. (2)

Original scientific paper

Izvorni znanstveni rad

\begin{abstract}
SUMMARY
Until now, no research has been carried out in Croatia into consumer preferences for a particular agricultural and food product by a choice experiment. Therefore, little data are available about Croatian consumers' preferences for social concerns (sustainability, biodiversity, rural development and animal welfare) with regard to the consumer choice and behavior favoring local pig breeds, in this case the Black Slavonian Pig breed. A survey was the method used to collect the data, and a survey questionnaire was used as an instrument. The survey was performed on a sample of $n=100$ Croatian consumers surveyed online using a hypothetical choice experiment. The data were analyzed using the three logit models: a multinomial logit model (MNL), random parameter logit (RPL), and an error component random parameter logit model (RPL-EC) in order to examine the consumers' heterogeneous preferences for fresh ham meat of the Black Slavonian Pig. The results suggest that the Croatian consumers appreciated a darker red fresh pork meat than the one obtained from the Black Slavonian Pig reared outdoors and semi-outdoor. They also prefer a fresh meat bearing a geographical information label, such as the continental Croatia and continental Croatia + PDO, to a fresh meat without a label.
\end{abstract}

Keywords: fresh meat, Black Slavonian Pig, choice experiment, multinomial logit, random parameter logit, error component random parameter logit

\section{INTRODUCTION}

Pig breeding in Croatia is a significant branch of livestock production and has a long tradition when it comes to the supply of a high-quality meat (Kralik et al., 2017; Kralik et al., 2012). Unfortunately, pork production in the Republic of Croatia does not satisfy the needs of domestic consumption, and about $50 \%$ of pork demand is satisfied by import (Kranjac et al., 2019; Grgić et al., 2015). Pork is an important source of nutrients in the population diet, and modern pork production is mainly based on the highly selected meat genotypes, obtained from the pigs bred in an intensive production system for the sake of a fresh meat market supply (Muñoz et al., 2018; Kralik et al., 2013). According to the same pork production scenario, a continuous development results in the genetically improved and more productive pig breeds and reduces the number of pigs in many local breeds that have achieved a lesser success in an intensive breeding and are currently threatened with extinction (Kušec et al., 2015). The preservation of biodiversity is one of the significant challenges to the modern society, and the described conventional production has encountered problems of lower product quality, lower animal resistance, animal waste management and animal welfare (Kušec et al., 2015). In line with this, the initiatives have been launched to preserve the local pig breeds and explore the ways to make them as competitive as possible in the current market conditions. The breeding of Black Slavonian Pigs is more economical and profitable because these pig breeds are adaptable to the extensive keeping conditions (Kralik et al., 2013) when compared to the modern ones and have several advantages, such as longevity and resistance.

(1) Sanja Jelić Milković, Mag. Eng. Agr. (sanja.jelic@fazos.hr),Prof. Dr. Ružica Lončarić, Prof. Dr. Krunoslav Zmaić, David Kranjac, Ph. D. - Josip Juraj Strossmayer University of Osijek, Faculty of Agrobiotechnical Sciences Osijek, Vladimira Preloga 1, Osijek, Republic of Croatia; (2) Assoc. Prof. Maurizio Canavari, Alma Mater Studiorum University of Bologna, Viale Fanin 50, Bologna, Italy 
Also, the low cost of accommodation facilities, modest food demand, and an excellent muscle and fat tissue quality of characterize this as a raw material to produce a high-quality meat and traditional products (Muñoz et al., 2018, Kralik et al., 2017; Kralik et al., 2013; Budimir et al., 2014). This way of keeping is in line with the animal welfare criteria because it positively impacts the pig's health, reduces the cost of breeding, and is an environmentally friendly production (Margeta et al., 2018). The benefits of indigenous pig breeds products are those that they have a high gastronomic and economic value that the consumers esteem (a unique quality, ecological gains, cultural and ethnic benefits). They are internationally recognized and protected by authenticity labels (Santos Silva and Tirapicos Nunes, 2013). The consumers' preferences and their choice when purchasing the food products are influenced by many factors, such as animal welfare, ecological factors, and health concerns. Nowadays, the consumers do not buy foodstuffs only because of their primary function but also because of the external signs, such as naturalness, authenticity, origin, and tradition (Cerjak et al., 2017; Fenger et al., 2015; Valkaj et al., 2013). Furthermore, the consumers take into account the intrinsic characteristics of food products (i.e., the visible product properties) and the extrinsic ones (i.e., brand, label, price, origin, production and nutrition information), as well as animal welfare and other credence attributes, such as the production methods that are focused on sustainable practices involving different consumer concerns, like those related to the environment, human health, and ethical food product characteristics (Grunert et al., 2018; Silva et al., 2018; Font-i-Furnols and Guerrero, 2014). Food supply has largely exceeded food demand, which turned the markets into demandoriented economies, and the goal of exchange and marketing is to better meet the consumers' needs, demands, and preferences (Vanhonacker et al., 2007). The Croatian consumers are not yet fully familiar with the impact of animal welfare on the meat quality, but they are interested in raising awareness and require transparency in food production. Generally, they want to know about the origin and traceability of the meat they buy in order to achieve a maximum utility (Mikuš et al., 2017). One of the greatest challenges in marketing is understanding the consumer preference diversity, and preference heterogeneity provides for an opportunity for different offers, market segments, and niches (Allenby and Rossi, 1999). This goal can be achieved by using a choice experiment, which nowadays is an important behavior analysis method in social sciences, with an application in market research, economics, agroeconomics, health economics, etc. (Aizaki, 2012). The choice experiment is the most commonly used method of perceptions because it enables a simultaneous multiple attribute estimation and responds to the numerous scientific and research questions. It provides an insight into consumer preferences, quantifying the compromises that the individuals are willing to make between the different bids, monetary and nonmonetary estimates, demand forecasts, etc. (Lancsar et al., 2017; De-Magistris and Gracia, 2016; Fiebig et al., 2010).

This paper aims to study the consumers' preferences for the Black Slavonian Pig's fresh meat and compare the results of three used models (multinomial logit, $\mathrm{MNL}$; random parameter logic, RPL; and an error component RPL, RPL-EC) in an exploratory study in order to examine the consumers' heterogeneous preferences.

\section{MATERIAL AND METHODS}

The study was conducted in April 2021 using a questionnaire to collect the preliminary data about consumer opinions and preferences for the product of interest, being the Black Slavonian Pig's fresh meat. The Black Slavonian Pig's fresh meat was selected for this research because it is in the process of the "Black Slavonian Pig meat" product name protection, to bear the mark of origin at a national level, and rearing the Black Slavonian Pig is in accordance with the animal welfare criteria, while an environmental protection issue is in line with the good livestock practices, representing a part of Croatia's historical and traditional identity (Black Slavonian Pig Meat-Origin Specification, 2019; Margeta et al., 2013). The pilot survey was conducted online by the online survey company Qualtrics Inc. The sampling was conducted randomly with a due concern for demographic variation (gender, age, place of residence, and the economic family status). We have obtained 145 questionnaires, but 100 Croatian consumers from the Adriatic and continental Croatia filled out the questionnaire correctly. This was a sufficient number of respondents for the pilot study to obtain the valid estimates for the stated preferences (Mariel et al., 2021). In the post-hock analysis according to Vecchio et al. (2020), the individuals who had a survey completion and response time lower than five minutes were removed from the sample due to their inattention during the online survey, signifying that the respondents have finished the survey too fast or have answered the questions randomly. Prior to the study's commencement, the respondents were asked to participate therein voluntarily and were screened by three questions, certifying that they were 18 years old, consumed pork, and were (at least partially) responsible for the purchase of foodstuffs in their households. The questionnaire consisted of choice experiment questions (which are the interest of this paper), the questions concerning the meat consumption, and of those pertaining to the factors and statements with regard to the purchase of fresh meat, measured on the 5-point Likert scale. The attributes and levels used in this study were selected subsequent to the revision of a previous consumer research results concerning the consumer preferences for an autochthonous pig breed and subsequent to the revision of a previous qualitative research. The chosen attributes and levels for this study are figured in Table 1. The experimental design was structured using the Ngene v1.2.1 
(ChoiceMetrics, 2018) software package to design an efficient or D-optimal design, which minimizes the asymptotic variance-covariance matrix (Bliemer et al., 2005). The design with 24 choice scenarios in total and the lowest D-error of 0.043416 was selected. However, to reduce the participants' fatigue, the choice design was divided into two blocks of 12 choices. In the choice experiment, the respondents were asked to select the most preferred option among the three differently labeled alternatives, representing the pork products obtained from the fresh ham of the Black Slavonian Pig and of the hybrid pig breeds, which represented a status quo option. Each respondent has evaluated 12 choice tasks, and the Qualtrics software has ensured that two blocks of 12 choice questions were presented to the same number of respondents, having thus prevented a systematic order effect.

Table 1. Attributes and levels of the fresh boneless pork ham used in the choice experiment Tablica 1. Atributi i leveli svježega mesa svinjskoga buta bez kostiju korišteni u eksperimentu odabira

\begin{tabular}{|l|l|}
\hline \multirow{4}{*}{ Product attribute / Atributi proizvoda } & Product level / Leveli proizvoda \\
\hline \multirow{2}{*}{ Color / Boja } & $70.00 \mathrm{HRK} / \mathrm{kg}$ \\
\cline { 2 - 2 } & $120.00 \mathrm{HRK} / \mathrm{kg}$ \\
\cline { 2 - 2 } & $170.00 \mathrm{HRK} / \mathrm{kg}$ \\
\hline \multirow{3}{*}{ Geographical information / Zemljopisna oznaka } & Dark red / Tamnocrvena \\
\cline { 2 - 2 } & Light red / Svijetlocrvena \\
\hline $\begin{array}{l}\text { Note: Croatian kuna (HRK) in April 2021, HRK 1 }=€ 7.572 \\
\text { Opaska: hrvatska kuna (kn) u travnju 2021., 1 kn }=7,572 €\end{array}$ & Continental Croatia / Kontinentalna Hrvatska \\
\cline { 2 - 2 } & Continental Croatia + PDO / Kontinentalna Hrvatska + ZOI \\
\cline { 2 - 2 } & Other regions / Ostale regije \\
\hline
\end{tabular}

Choice experiments are used to simulate a real-life purchasing situation, in which the consumers choose between the products with similar attributes and allow the researchers to estimate the trade-offs among the different alternatives (Khachatryan et al., 2021; Lusk et al., 2003). To minimize this research's potential hypothetical bias, a cheap talk was organized prior to the choice experiment, following the guidelines specified by Cummings and Taylor (1999) and Tonsor and Shupp (2011). The inclusion of cheap talk prior to the experiment has influenced the WTP estimate level and has produced the more reliable estimates (Tonsor and Shupp, 2011). The choice data were analyzed by a multinomial logit model (MNL), random parameter logit (RPL), and an error component random parameter logit model (RPL-EC) using the following packages: mlogit (Croissant, 2020), gmnl (Sarrias and Daziano, 2017), and the Imtest (Zeileis and Hothorn, 2002) in R (version 4.0.2).

\section{RESULTS AND DISCUSSION}

This study was developed using a discrete choice experiment (DCE) with the alternative specific constants (labeled), based on a stated choice (SC). This approach is attribute-based and is useful to explore a consumer preference for the fresh meat of the Black Slavonian Pig breed. The root of the choice experiment (CE) lies in Lancaster's (1966) research of consumer theory, purporting that the consumer preferences or consumer utility are not driven by a direct consumption of a mer- chandise but rather by its attributes (Giampietri et al., 2016). The consumer selects an alternative that assures him or her a maximum utility (Fiebig et al., 2010; Train, 2009). According to Khachatryan et al. (2021), the choice experiment models are based on a random utility theory, where utility is represented by $\mathrm{U}_{\mathrm{ijs}}$ and is estimated as follows:

$$
U_{i j s}=\beta^{\prime} x_{i j s}+\varepsilon_{i j t} .
$$

Thereby, an individual derives utility from the option $j$ in the scenario $s$, and $x_{i j s}$ is a vector of the observable attribute variables. In our study, it represents a variable of color, geographical information, and price, while the $\varepsilon_{i j t}$ represents an unobservable or random (error) term. Thus, in our study concerning the selected attributes and levels for the RPL-EC model, the utility function presented above is specified as follows:

$$
\begin{aligned}
U_{i j s}= & A S C+\beta_{1} P R I C E_{i j s}+\beta_{2} C O L_{i j s}+ \\
& \beta_{3} G E O_{i j s}+\mu_{i} Z_{i j s}+\varepsilon_{i j s} .
\end{aligned}
$$

Hereby, the ASC is an alternative specific constant, called the status quo variable in the literature, $\mathrm{PRICE}_{\mathrm{ijt}}$ represents the price of $1 \mathrm{~kg}$ of fresh boneless pork ham (gluteus medius) of the Black Slavonian Pig's alternative $j, \mathrm{COL}_{\mathrm{ijs}}$ represents the fresh meat color (dark, light) of the alternative $j, \mathrm{GEO}_{\mathrm{ijs}}$ represents a geographical information (continental Croatia, continental Croatia + PDO, and other regions) of the alternative $j, Z_{i j s}$ is a normally 
distributed zero mean error component, set to 0 in the utility of the status quo alternative (Wongprawmas and Canavari, 2017), and the $\varepsilon_{\mathrm{iji}}$ is the error term. The main effect variable includes the price and the alternative specific attributes (color and geographical indicator), and all variables except the price are effect coded. It assumes the value +1 if the product is of a darker red color and is produced in continental Croatia with the PDO label, assumes the value of -1 if the product is of a lighter red color and is produced in other regions of Croatia, and it is set to 0 otherwise. Table 2 illustrates the sociodemographic characteristics of the pilot study sample.

Table 2. Sociodemographic characteristics of the pilot study

Tablica 2. Deskriptivna statistika pilot-istraživanja

\begin{tabular}{|c|c|}
\hline $\begin{array}{l}\text { Socio-demographic characteristics }(\%) / \\
\text { Sociodemografske karakteristike ispitanika }\end{array}$ & $\begin{aligned} \text { Sample }(\mathrm{n}=100) / \\
\text { Uzorak }(n=100)\end{aligned}$ \\
\hline \multicolumn{2}{|l|}{ Gender / Spol } \\
\hline Male / Muško & 33 \\
\hline Female / Žensko & 67 \\
\hline \multicolumn{2}{|l|}{ Age of respondents / Dob ispitanika } \\
\hline $20-34$ & 24 \\
\hline $35-54$ & 52 \\
\hline $55-64$ & 19 \\
\hline$>64$ & 5 \\
\hline \multicolumn{2}{|l|}{ Place of residence / Mjesto stanovanja } \\
\hline Urban / Urbano & 69 \\
\hline Rural / Ruralno & 31 \\
\hline \multicolumn{2}{|l|}{ Economic status / Ekonomski status } \\
\hline Substantially below average / Znatno ispod prosjeka & 3 \\
\hline Below average / Ispod prosjeka & 7 \\
\hline Average / Oko prosjeka & 51 \\
\hline Above average / Iznad prosjeka & 34 \\
\hline Substantially above average / Znatno iznad prosjeka & 5 \\
\hline
\end{tabular}

In this study, all models are estimated as being based on 1,200 choices made by 100 respondents who have individually performed 12 choice tasks. The RPL-EC model was estimated considering a panel data structure and using 100 Halton draws for simulation. A multinomial logit model (MNL), random parameter logit (RPL), and an error component random parameter logit model (RPL-EC) were used to elicit the consumer preferences for different fresh ham attributes and levels. As a baseline model, the MNL model was used. According to McFadden (1974), it is assumed that the consumers have the same preferences and homogeneous taste for the observed attributes, which, according to Wang et al. (2018), is likely to be violated. That is why the mixed logit models (RPL and RPL-EC, respectively) were used. The mixed logit models can capture an unobserved preference heterogeneity and allow for a flexible variance-covariance structure of an unobservable utility portion (Balogh et al., 2016). In the study, the data were primarily analyzed using the MNL model, and the models accounting for the respondents' heteroge- neity, such as the RPL and RPL-EC, were used subsequently because the consumers' preference heterogeneity should have been considered (Wongprawmas and Canavari, 2017). We can say that the mixed models such as these used in this study add value over a baseline MNL model because they mitigate the limitations of the MNL model, such as the changes in the odds of preference of one class over the other (i.e., the independence from an irrelevant alternative), can be used for the panel data, and can incorporate the differences in taste unrelated to the observed characteristics (Liu, 2019).

The study aimed to investigate the heterogeneity of Croatian consumers' preferences for the fresh meat of the Black Slavonian Pig. The first column in Table 3 illustrates the results for the baseline MNL model, and the second and third column represent the RPL and RPL-EC model to analyze the Croatian consumers' preference heterogeneity. We have compared the models by virtue of the information criteria and fit statistics integrity. 
Table 3. Estimated parameters of the MNL, RPL, and RPL-EC models for the main effect variables

Tablica 3. Procijenjeni parametri MNL, RPL i RPL-EC modela za glavne varijable efekta

\begin{tabular}{|c|c|c|c|}
\hline \multirow[t]{2}{*}{ Mean estimates / Prosječne procjene } & \multicolumn{3}{|c|}{ Coefficients / Koeficijenti } \\
\hline & MNL & RPL & - RPL-EC \\
\hline $\begin{array}{l}\text { Intercept (BSP reared outdoors) / } \\
\text { Odsječak CSS-a, uzgoj na otvorenome }\end{array}$ & $0.9869140^{* * *}$ & $1.07473008^{* * *}$ & $3.4657487^{* * *}$ \\
\hline $\begin{array}{l}\text { Intercept (BSP reared semioutdoors) / } \\
\text { Odsječak CSS-a, uzgoj na poluotvorenome }\end{array}$ & $0.3385328^{* *}$ & 0.14716557 & $2.3577756^{* * *}$ \\
\hline $\begin{array}{l}\text { PRICE / } \\
\text { Cijena }\end{array}$ & $-0.0093279 * * *$ & $-0.01088542^{* * *}$ & $-0.0158636^{* * *}$ \\
\hline $\begin{array}{l}\text { COLOR / } \\
\text { Boja }\end{array}$ & 0.0547374 & 0.07630814 & 0.0864615 \\
\hline \multicolumn{4}{|c|}{ GEOGRAPHICAL INFORMATION / Geografska oznaka } \\
\hline $\begin{array}{l}\text { Continental Croatia / } \\
\text { Kontinentalna Hrvatska }\end{array}$ & $0.3164386^{* * *}$ & $0.36466389 * * *$ & $0.5314190^{* * *}$ \\
\hline $\begin{array}{l}\text { Continental Croatia + PDO / } \\
\text { Kontinentalna Hrvatska + ZOI }\end{array}$ & 0.1472973 & $0.22004450^{*}$ & $0.3812660^{*}$ \\
\hline \multicolumn{4}{|c|}{ St. dev. of mean estimates (std. err.) / Standardne devijacije prosječnih procjenitelja } \\
\hline $\begin{array}{l}\text { COLOR / } \\
\text { Boja }\end{array}$ & 0.0634926 & $0.48962042^{* * *}$ & $-0.8005210^{* * *}$ \\
\hline \multicolumn{4}{|c|}{ GEOGRAPHICAL INFORMATION / Geografska oznaka } \\
\hline $\begin{array}{l}\text { Continental Croatia / } \\
\text { Kontinentalna Hrvatska }\end{array}$ & & $0.38921892^{* *}$ & $0.6610362^{* * *}$ \\
\hline $\begin{array}{l}\text { Continental Croatia + PDO / } \\
\text { Kontinentalna Hrvatska + ZOI }\end{array}$ & & $0.77610102^{* * *}$ & $0.9325418^{* * *}$ \\
\hline $\begin{array}{l}\text { Number of respondents / } \\
\text { Broj ispitanika }\end{array}$ & 100 & 100 & 100 \\
\hline $\begin{array}{l}\text { Number of observations / } \\
\text { Broj promatranja }\end{array}$ & 1200 & 1200 & 1200 \\
\hline Log-likelihood & -1226.5 & -1178.6 & -806.93 \\
\hline AIC & 2466.012 & 2385.163 & 1649.863 \\
\hline BIC & 2496.552 & 2456.424 & 1741.484 \\
\hline
\end{tabular}

Note: MNL - multinomial logit, RPL - random parameter logit, RPL-EC - error component random parameter logit, LR test - log likelihood ratio test, AIC - Akaike information criteria, BIC - Bayesian information criteria BSP - Black Slavonian Pig's meat, PDO - protected designation of origin * ${ }^{* *}$, and ${ }^{* *}$ represent a significant level at 0.05, 0.01, and 0.001 / Opaska: MNL - multinomni logit model, RPL - model slučajnih parametara, RPL-EC - model slučajnih parametara — pogreške u komponentama, LR test - test omjera vjerodostojnosti, AIC - Akaikeov informacijski kriterij, BIC - Bayesov informacijski kriterij BSP - meso crne slavonske svinje, PDO - zaštićena oznaka podrijetla *, ** $i$ *** predstavljaju značajnu razinu pri 0,05, 0,01 i 0,001

In Table 3, the information criteria are also presented: a log likelihood ratio test (LR test), Akaike information criteria (AIC), and the Bayesian information criteria (BIC), which can be used to describe a relative appropriateness of the three presented models. The higher is the value of the log likelihood criteria and the lower is the information of the AIC and BIC criteria; the better a model fits the data. According to the data presented in Table 3, it may be primarily noticed that the RPL model provides an improvement to the baseline MNL model in the information criteria (AIC and BIC) (2385.163 in fit; 2456.424 in the RPL vs. 2466.012; 2496.552 in the MNL). The RPL and RPL-EC models allow for a preference heterogeneity among consumers and better fit the data than the baseline MNL model. However, all criteria suggest that the RPL-EC model (1649.863; 1741.484) fits the data better than the MNL and RPL model, and the value of the RPL-EC model is closer to 0 . Moreover, the standard deviations of the RPL-EC model are statistically significant, indicating that the consumers' preferences for geographical indicators (continental Croatia and continental Croatia + PDO) are heterogeneous and that the RPL-EC model is appropriate (Table 3). Continental Croatia + PDO has the highest standard deviations among the presented attributes. This means that there is a high heterogeneity among the surveyed consumers concerning this attribute of the Black Slavonian Pig's fresh meat. 
According to the data in Table 3, it is observable that the fresh boneless ham produced of the meat of the Black Slavonian Pig reared outdoors and semioutdoors is preferred to a hybrid meat obtained from a pig reared conventionally, which represents a status quo option. In general, the consumers have obtained a lower utility from the status quo option than from the designed alternatives. The price attribute is negative and highly significant, which is in accordance with the econometric theory, signifying that the price has a negative impact on consumer utility. Each additional price unit would decrease the utility by 0.0159 , i.e., given the same price, the consumers would prefer the option of the fresh meat obtained from the Black Slavonian Pigs reared outdoors to that of the meat of the Black Slavonian Pigs reared semioutdoors slightly more. A solid line in Figure 1 represents a darker red fresh ham meat obtained from the Black Slavonian Pigs reared outdoors bearing the label of "continental Croatia + PDO," and a dashed line represents the light red fresh ham meat obtained from the Black Slavonian Pigs reared semioutdoors, bearing the label of "continental Croatia." The results demonstrate that the consumers would select a darker meat obtained from the Black Slavonian Pigs reared outdoors and bearing a PDO sign up to $180.00 \mathrm{HRK} /$ $\mathrm{kg}$ (Figure 1). In any case, at the same price level, the consumers would prefer the fresh Black Slavonian Pig meat to the regular porcine meat (i.e., to a hybrid meat of the pigs reared conventionally). According to the data presented in Table 3, it is also observable that the dark red meat color increases consumer utility while the light red meat color decreases it, although the meat color is not statistically significant, denoting that the consumer preferences are not normally distributed but are rather grouped. Regarding a geographical indicator, the presence of a label "reared in continental Croatia" has increased a selection probability when compared with the fresh ham of the pigs reared in other regions of Croatia and the fresh ham of the pigs bearing no such label (a status quo option). The "protected designation of origin" (PDO) label also adds some utility to Croatia's continental provinces (Figure 1).

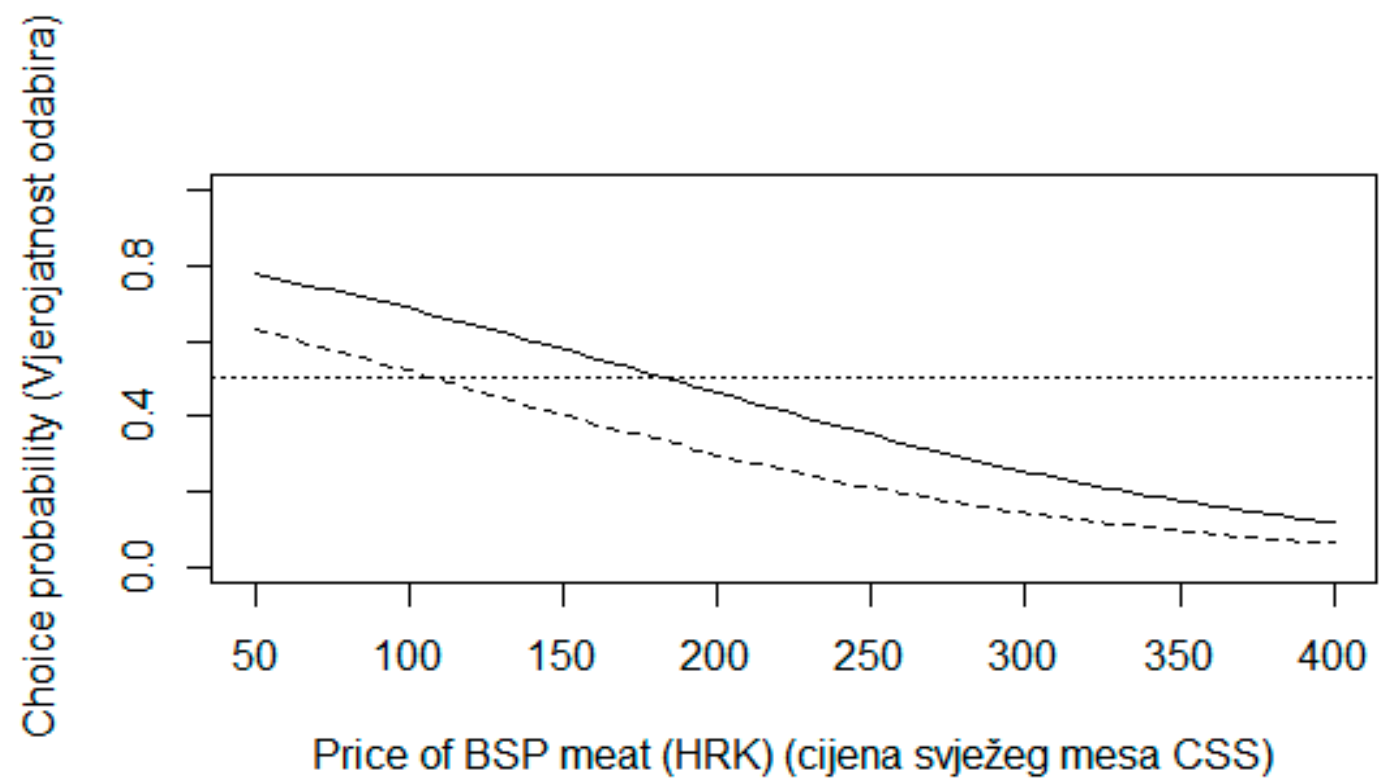

Figure 1. Probability of choosing an option among two alternatives

Grafikon 1. Vjerojatnost odabira opcije između dviju mogućnosti

The selection of attributes and levels that are to be used in a choice experiment is the most significant stage of designing the experiment, as it must reflect the products' characteristics and dimensions, being vital to the consumers in the process of decision-making and purchasing (Sahelices et al. 2016). Thus, by virtue of this study, a valuable preliminary information (the $\beta$ estimates) is collected for each attribute level with regard to the future research, providing intelligence on how the model parameters are held constant and the data on consumers' heterogeneity preferences.

\section{CONCLUSION}

According to this study's empirical results, it may be concluded that the consumers have positively valued the outdoor and semioutdoor production systems in comparison to a conventional pig rearing system. The consumers have also preferred a darker red color of the fresh Black Slavonian Pig's meat and have rather selected the fresh meat labeled with a geographical information, such as that of "continental Croatia" or "continental Croatia + PDO," than the fresh meat without a label. Based on these preliminary results, the Croatian Black 
Slavonian Pig producers may obtain the higher prices for their commodities if they are produced according to the Black Slavonian Pig Meat-Origin Specification (2019) and if they bear the geographical indicator labels. These preliminary findings also suggest that it is necessary to notify the consumers about a production system, origin, and production traceability by virtue of labels in order to assist them to make the informed purchasing decisions and gain a higher utility when buying and consuming the meat obtained from the Black Slavonian Pig. Although this study has some limitations, these preliminary results may be used for a wider research, extended to a larger number of respondents in order to further investigate the reasons of consumers' heterogeneity preferences, which were also detected herein. The future studies should also investigate the impact of respondents' sociodemographic characteristics, consumption habits, interaction terms and willingness to pay for the fresh porcine meat of indigenous pig breeds. Despite these limitations, this study indicates that an appropriate labelling and the information on a product rendered from the fresh Black Slavonian Pig meat could positively affect the consumers' preferences.

\section{REFERENCES}

1. Aizaki, H. (2012). Choice Experiment Applications in Food, Agriculture, and Rural Planning Research in Japan. AGri-Bioscience Monographs, 2(1), 1-46. https://doi:10.5047/agbm.2012.00201.0001

2. Allenby, G. M., Rossi, P. E. (1999). Marketing models of consumer heterogeneity. Journal of Econometrics, 89, 57-58. https://doi:10.1016/S0304-4076(98)00055-4

3. Balogh, P., Bekesi, D., Gorton, M., Popp, J., Lengyel, P. (2016). Consumer willingness to pay for traditional food products. Food policy, 61, 176-184. https://doi:10.1016/j.foodpol.2016.03.005

4. Budimir, K., Djurkin Kušec, I., Lukić, B., Džijan, S., Margeta, V., Kušec, G. (2014). Possibilities of branding the pork in Croatia - review. Acta Agraria Kaposváriensis, $18(1), 115-121$.

5. Bliemer, M.C.J., Rose, J.M. (2005). Efficient Designs for Alternative Specific Choice Experiment. Working paper IKTLS-WP-05-04, Institute of Transport and Logistics Studies, Australia, 1-20.

6. Cerjak, M., Petrčić, M., Karolyi, D. (2017). Effect of Information about Animal Feeding on Consumer Acceptability of Sausages from Turopolje Pig Breed. Agriculturae Conspectus Scientificus, 82(2), 151-154.

7. ChoiceMetrics. (2018). Ngene 1.2 User Manual \& Reference Guide. Australia.

8. Cummings, R.G., Taylor, L.O. (1999). Unbiased value estimates for environmental goods: a cheap talk design for the contingent valuation method. The American Economic Review, 89(3), 649-665.

9. Croissant, Y. (2020). Estimation of Random Utility Models in R: The mlogit Package. Journal of Statistical Software, 95(11), 1-41. https://doi:10.18637/jss. v095.i11.
10. De-Magistris, T., Gracia, A. (2016). Do consumers care about organic and distance labels? An empirical analysis in Spain. International Journal of Consumer Studies, 38, 660-669. https://doi:10.1111/ijcs.12138

11. Fenger M.H., Aschemann-Witzel J., Hansen F., Grunert K.G. (2015). Delicious words - Assessing the impact of short storytelling messages on consumer preferences for variations of a new processed meat product. Food Qual Prefer, 41, 237-244.

12. Fiebig, D. G., Keane, M. P., Louviere, J., Wasi, N. (2010). The Generalised Multinomial Logit Model: Accounting for Scale and Coefficient Heterogeneity. Marketing Science, 29(3), 393- https://doi:421. 10.1287/mksc.1090.0508

13. Font-i-Furnols, M., Guerrero, L. (2014). Consumer preference, behaviour and perception about meat and meat products: An overview. Meat Science 98(3), 361-371. https://doi.org/10.1016/j.meatsci.2014.06.025

14. Giampietri, E., Koemle, D.B.A., Yu, X., Finco, A. (2016). Consumers' Sense of Farmers' Markets: Tasting Sustainability or Just Purchasing Food? Sustainability, 8(11), 2-14. https://doi:10.3390/su8111157

15. Grgić, I., Zrakić, M., Hadelan, L. (2015). Proizvodno potrošna bilanca svinjskog mesa u Hrvatskoj. Meso, 17(1), 138-144.

16. Grunert, K.G., Sonntag, W.I., Glanz-Chanos, V., Forum, S. (2018). Consumer interest in environmental impact, safety, health and animal welfare aspects of modern pig production: Results of a cross-national choice experiment. Meat Science, 137, 123-129. https://doi.org/10.1016/j.meatsci.2017.11.022

17. Khachatryan, H., Rihn, A., Wei, X. (2021). Consumers' Preferences for Eco-labels on Plants: The Influence of Trust and Consequentiality Perceptions. Journal of Behavioral and Experimental Economics, 91, 101659. https://doi:10.1016/j.socec.2020.101659

18. Kralik, G., Margeta, V., Kralik, I., Budimir, K. (2012). Specifičnosti svinjogojske proizvodnje u Republici Hrvatskoj - stanje i perspektive. Krmiva, 54(2), 59-70.

19. Kralik, G., Margeta, V., Luković, Z., Kralik, I. (2013). Stanje i smjernice razvoja svinjogojstva s posebnim osvrtom na istočnu Hrvatsku. Stočarstvo, 67(4), 151159.

20. Kralik, I., Tolušić, Z., Jelić, S. (2017). Proizvodnja svinjskog mesa u Republici Hrvatskoj i u zemljama Europske unije. Agroeconomia Croatica, 7(1), 66-78.

21. Kranjac, D., Zmaić, K., Štefanić, I., Jelić Milković, S., Raguž, N., Erjavec, E. (2019). Simulation of main agrarian policy indicators within beef meat market in The Republic of Croatia by AGMEMOD partial equilibrium model. Poljoprivreda, 25(2), 45-51. https://doi:10.18047/poljo.25.2.7

22. Kušec, G., Dovč, P., Karolyi, D., Čandek Potokar, M. (2015). Local pig breeds and pork products in Croatia and Slovenia - unexploited treasure. Poljoprivreda, 21(1), 16-21. https://doi:10.18047/poljo.21.1.sup.3

23. Lancaster, K.J. (1966). A New Approach to Consumer Theory. J. Political Econ, 74(2), 132-157.

24. Lancsar, E., Fiebig, D. G., Hole, A. R. (2017). Discrete Choice Experiments: A Guide to Model Specification, 
Estimation and Software. Pharmaco Economics, 35, 697-716. https://doi:10.1007/s40273-017-0506-4

25. Liu, T.M. (2019). Using RPL Model to Probe Trade-offs among Negative Externalities of Controlling Invasive Species. Sustainability, 11(6184), 1-17. https://doi.org/10.3390/su11216184

26. Lusk, J., Roosen, J., Fox, J. (2003). Demand for Beef from Cattle Administered Growth Hormones or Fed Genetically Modified Corn: A Comparison of Consumers in France, Germany, the United Kingdom, and the United States. American Journal of Agricultural Economics, 85, 16-29.

27. Margeta, V., Budimir, K., Margeta, P. (2013). Održiva svinjogojska proizvodnja na obiteljskim gospodarstvima. Zbornik radova IX. savjetovanja uzgajivača svinja u Republici Hrvatskoj, Mehnet, Ž. (ur.). Križevci. Hrvatska poljoprivredna agencija. 19-22.

28. Margeta, V., Gvozdanović, K., Kušec, G., Djurkin Kušec, I., Galović, D., Radišić, Ž., Margeta, P. (2018). Zaštita mesa crne slavonske svinje - fajferice oznakom izvornosti. Zbornik sažetaka 53. hrvatskog i 13. međunarodnog simpozija agronoma, Vodice, Hrvatska, 18-22.2.2018., 215-216.

29. Mariel, P., Hoyos, D., Meyerhoff, J., Czajkowski, M., Dekker, T., Glenk, K., Jacobsen, B., Liebe, U., Olsen, S.B., Sagebiel, J. Thiene, M. (2021). Environmental Valuation with Discrete Choice Experiments, Guidance on Design, Implementation and Data Analysis. Springer, Switzerland. https://doi:10.1007/978-3-030-62669-3

30. McFadden, D. (1973). Conditional Logit Analysis of Qualitative Choice Behavior. In Zarembka, P. (ed.), Frontiers in Economics, New York: Academic Press.

31. Black Slavonian pig meat - Origin Specification (Meso crne slavonske svinje - Oznaka izvornosti) (2019). Product specification. Poljoprivredno - uslužna zadruga "LETA", 1-12. https://poljoprivreda.gov.hr/UserDocslmages/ dokumenti/hrana/proizvodi_u_postupku_zastite-zoizozp-zts/Specifikacija_meso_crne_slavōnske_svinje 2019.pdf (pristupljenō 10. lip̄nja 20̄19.)

32. Mikuš, T., Mikuš, O., Kozačinski, L., Mesić, Ž. (2017). Croatian meat consumer attitudes towards animal welfare-friendly products and production. Meso, 19(4), 324330. https://doi:10.31727/m.19.4.6

33. Muñoz, M., Bozzi, B., Garcı'a, F., Nu'ñez, Y., Geraci, C., Crovetti, A., Garcı'a-Casco, J., Alves, E., Škrlep, M., Charneca, R., Martins, J. M., Quintanilla, R., Tibau., J., Kušec, G., Djurkin-Kušec, I., Mercat, M. J., Riquet,J., Estelle', J., Zimmer, C., Razmaite, V., Araujo., J. P., Radović, Č., Savić, R., Karolyi, D., Gallo, M., ČandekPotokar, M., Fontanesi, L., Ferna'ndez, A. I., O' vilo, C. (2018). Diversity across major and candidate genes in European local pig breeds. PLOS ONE, 13(11), 1-30.

34. R Core Team (2020). R: A language and environment for statistical computing. R Foundation for Statistical Computing, Vienna, Austria.

URL https://www.R-project.org/.
35. Sahelices, A., Mesías, F. H., Escribano, M., Gaspar, P., Elghannam, A. (2017). Are quality regulations displacing PDOs? A choice experiment study on lberian meat products in Spain, Italian Journal of Animal Science, 16(1), 9-13. https://doi.org/10.1080/1828051X.2016.1266704

36. Santos Silva, J., Tirapicos Nunes, J. L. (2013). Inventory and characterisation of traditional Mediterranean pig production systems. Advantages and constraints towards its development. 8th International Symposium on the Mediterranean Pig, Slovenia, Ljubljana, October 10th-12th, 2013. Acta agriculturae Slovenica, Supplement 4, 61-67.

37. Sarrias, M., Daziano, R. (2017). Multinomial Logit Models with Continuous and Discrete Individual Heterogeneity in R: The gmnl Package. Journal of Statistical Software, 79(2), 1-46. https://doi:10.18637/jss. v079.i02.

38. Silva, A. G., Canavari, M., \& Wander, A. E. (2018). Consumer preferences and willingness-to-pay for integrated production label on common beans. Economia Agro-Alimentare, 20(1), 11-28. https://doi:10.3280/ECAG2018-001002

39. Train, K. E. (2009). Discrete Choice Methods with Simulation. Cambridge University Press. Second edition. ISBN 978-0-521-74738-7. Page 14.

40. Tonsor, T., Shupp, S. (2011). Cheap talk scripts and online choice experiment: "Looking beyond the mean". Amer. J. Agr. Econ., 93(4), 1015-1031.

41. Valkaj K., Cerjak M., Kalit S., Rako A., Wendorff W.L. (2013). Do consumers from Međimurje region recognise their autochthonous Turoš cheese? Mljekarstvo, 63, 211 219.

42. Vanhonacker, F., Verbeke, W., Van Poucke, E., Tuyttens, F.A.M. (2007). Segmentation based on consumers' perceived importance and attitude toward farm animal welfare. International Journal of Sociology of Food and Agriculture, 15(3), 84-100. http://dx.doi.org/1854/10718

43. Vecchio, R., Caso, G., Cembalo, L., \& Borrello, M. (2020). Is respondents' inattention in online surveys a major issue for research? Economia Agro-Alimentare, 22(1), 1-18.

44. Wang, J., Ge, J., Ma, Y. (2018). Urban Chinese Consumers' Willingness to Pay for Pork with Certified Labeled: A Discrete Choice Experiment. Sustainability, 10(603), 5-14. https://doi.org/10.3390/su10030603

45. Wongprawmas, R., Canavari, M. (2017). Consumers' willingness-to-pay for food safety labels in an emerging market: The case of fresh produce in Thailand. Food Policy, 69, 25-34. https://doi:10.1016/j.foodpol.2017.03.004

46. Zeileis, A., Hothorn, T. (2002). Diagnostic Checking in Regression Relationships. $R$ News, 2(3), 7-10. https://CRAN.R-project.org/doc/Rnews/. 


\section{EKSPERIMENT ODABIRA NA SVJEŽEM MESU CRNE SLAVONSKE SVINJE: PRELIMINARNO ISTRAŽIVANJE}

\section{SAŽETAK}

Dosada u Hrvatskoj metodom eksperimenta odabira nisu provedena istraživanja koja se bave preferencijama potrošača prema određenomu poljoprivredno-prehrambenom proizvodu. Dostupno je malo podataka o preferencijama hrvatskih potrošača s obzirom na društvenu odgovornost (očuvanje bioraznolikosti, održivost ruralnoga prostora i dobrobit životinja) i odnos prema izboru i ponašanju potrošača u korist lokalnih pasmina svinja, u ovome slučaju pasmine crne slavonske svinje. Za prikupljanje podataka korištena je anketa, a kao instrument korišten je anketni upitnik. Istraživanje je provedeno na uzorku od $n=100$ hrvatskih potrošača, anketiranih putem interneta s pomoću hipotetskoga eksperimenta odabira. Podatci su analizirani s pomoću triju logit modela: multinomnoga logit model (MNL), modela slučajnih parametara (RPL) i modela slučajnih parametara - pogreške u komponentama (RPL-EC) kako bi se ispitale heterogene sklonosti potrošača prema svježemu butu crne slavonske svinje. Prema podatcima istraživanja, hrvatski potrošači preferiraju tamniju crvenu boju svježega svinjskog mesa crne slavonske svinje uzgajane u otvorenome i poluotvorenom sustavu držanja. Također, u odnosu na meso bez oznaka, potrošači preferiraju svježe meso s geografskim oznakama kontinentalna Hrvatska i kontinentalna Hrvatska + ZOI.

Ključne riječi: svježe meso, crna slavonska svinja, eksperiment odabira, multinomni logit, model slučajnih parametara i model slučajnih parametara — pogreške u komponentama

(Received on June 30, 2021; accepted on September 22, 2021 - Primljeno 30. lipnja 2021.; prihvaćeno 22. rujna 2021.) 